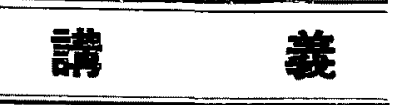 \\ 金 屬表面の光 學 常 數 \\ 大久保準 三*
}

\section{は しがき}

金啳の性質は內部節ち金屬全體としての性質と，外部 郎与金翼表面の性質上に大别し得る。金屬の熱傳導，電氣 傳導，磁性，彈性等忙ての內部性質であり，表面張力，電解 飞對する性筫，觸媒作用，光電效果，熱電子の放出，光の反 射屈折、嗳收等はこの外部性質である。金第のての外部性 質怡その表面の壯態特にその表面に生ずる非金屬性の被

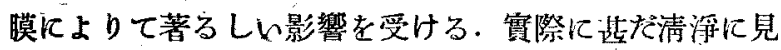
える金屬の表面でさへも，金屬そのものではなく，極めて 薄い酸化物の被膜で蔽はれてみることが甚だ多い，從つ てての表面被膜が金屬の性質に及海す影響，更几かやう

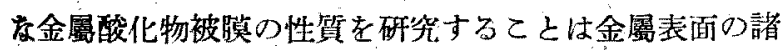

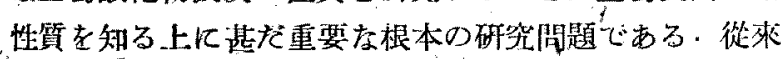

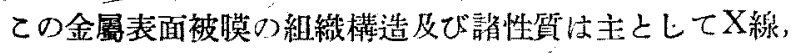

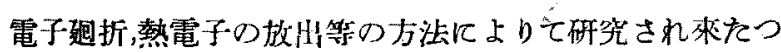

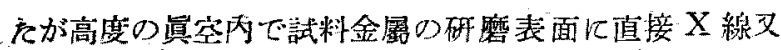
は電子を入射させるか或はてれを熱陰極として熱電子を 放壮させるからであるから何れにしても複雜な装置を要 する．金屬表面の光に對する性質を研究すること必亦表 面の性質を研究する一つの方洗である。師ち金屬の表面 一入射した光は屈据して金屬內一進む間江全反射索受け

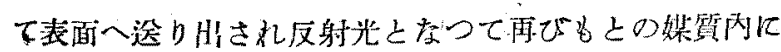
䠰る。從つて金屬表面に於ける光の屈折率 $(n)$ 吸收係數 $(\kappa)$ 及び反射率 $(R)$ 放その金屬の品質及びそり表面の性質 によりて著るしく異なるわけで,ての三つの量節ち金屬 裴面の光學常數老測定してその表面の概觀的性㲁索檢べ 得るわけである．以下ての光學常數の测定方法並に現在 まで行得られた测定結果国概要を述べをい。

\section{光㦛常數の測定方法}

金濁表面の光學常數の测定方法隹ドルューブ(P.Drude) が創めをとしてょい，光の電磁波論に基づくトルューデ

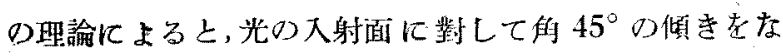

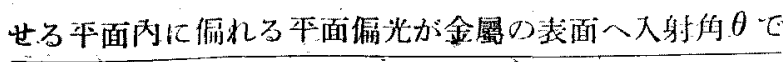

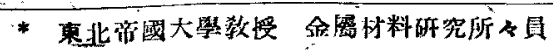

入射したとするとこの光は入射面內と，それの直角な平 面內とに偏れる二つの相等しい强さの平面偏光と考入て

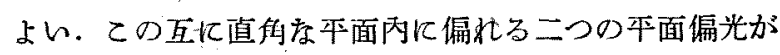
金屬の表面より若干の距離內部一進んで之こで全反射に より、て再び表面へ揆り歸され所謂反射光となるなでて進 む距離は同一でない，從つて金屬によりて吸收される量

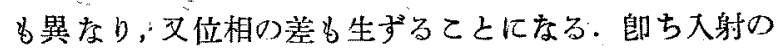
直前に於ては强さが相等しく，位相の差のない互に直角 に偏れる二つの和面偏光も，反射の後には强さの異なる (この强さり此を $\tan \psi$ と表はす)位相の差(A)を有する 二つの平面偏光となる：それ故ての反射光は最早平面偏 光でなく䄇圓偏光上なるかけで，上の $\tan \psi$ 及び 定すると，その表面の基本の光學性質である屈折率 $(n)$ 及 び吸收係数 $(\kappa)$ は

$$
\begin{aligned}
& n=\sin \theta \tan \theta \frac{\cos 2 \psi}{1+\cos \Delta \sin 2 \psi} \\
& \kappa=\sin \Delta \tan 2 \psi
\end{aligned}
$$

によりて與へられ，反射率 $(R)$ 站

$$
R=\frac{n^{2}\left(1+\kappa^{2}\right)+1-2 n}{n^{2}\left(1+\kappa^{2}\right)+1+2 n}
$$

から計算される。

この理論に基づいて，整ふり金屬表面の屈折率及び吸 收係數の测定が屡:試みられ，多數の文献として殘つて はわるが表面り研磨方法及び研暗後り處理取扱ひが同一 でないためその結果も統一を缺を，只極めて大體の程度 を知り得るに過ぎないりは遺憾である。乙の點に注意し 近年に至りローリー $(\mathrm{H} \text {. Lowry })^{(1)}$ とトロンスタット (P. Tronstad)(2) は金䐂の品質に上り，研磨の方法に上り，又

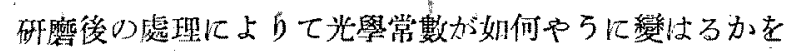
組織的に研究しよらと試みた。

これ委でこの光學常數の测定には主として偏光分光器 のみが胞ひられて居たが位相の差及び二つの偏光の强さ の比老測定する上に精確を期し難いので、トロンスタッ

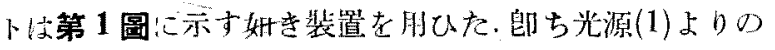

(1) H. Lowry, R. L. Moore, Phil. Mag., 13 (1932), 938

(2) P. Tronstad, Trans. Faraday Soc., 29 (1933), 502. 
光をレンズ (2) 值解プリズム(3) を經てモノクロメーター の細吵(4)の上に光源の像老結ばせる.ての光はてク口 メーターのコリメーターレンズによりて平行光となりプ リズム (6)にて分散された娞望遠籍のレンズによりて細 隙 (5)の上に任意の單巴光の像を縕ぶ.この單色光はレン ズ (7)により再び本行光となり，偏光子゙ニコルプリズム・ (8)絞り (9) 及び四分の一波長板 (10) を通過して試料全 虽り表面 (12) 几入射する。この試料金屬表面で反射し

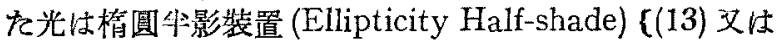
(14)\},絞り (9) 及び檢光子ニコルプリズム (15) を經て望 遠鏡 (16)で觀测する。試料金屬はそれの表面は處理例一 ば電解の間に於ける光學常數の變化又種々の溶液中に 浸した場合に於ける光學常數の變はりをも測定し得られ るやうに豫め入射光及び反射光が通過する二つの硝子空，

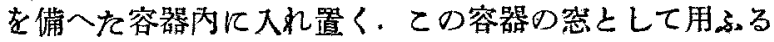
硝子は歪みのないものを注意して排んである，又この容 器內で試料金屬表面を陰極又は陽極として電解し得られ るやう旣ち容器を電解槽としてる用い得られるやらに電

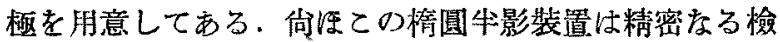
糖計にも用ひられて居る装置であつて偏光面の力向を精 確に求めるためにての锡合にる利用したわけである。

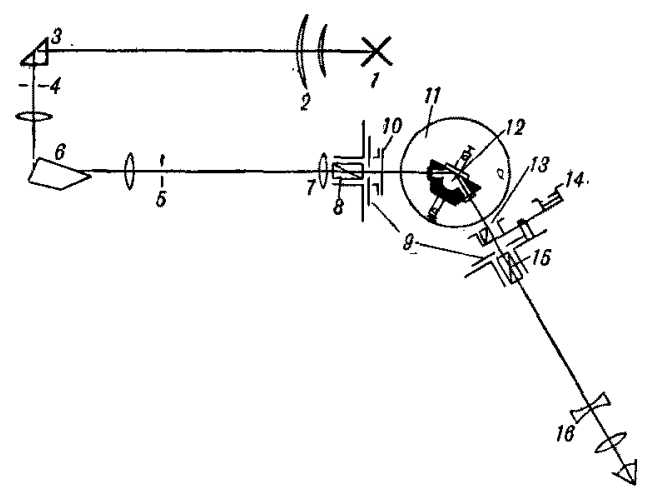

第 1 圖

この装置で金蚭表面の光學常數を测定するには先づ四 分め一波長板孝除き置き，㭙國牛影及び检光子ニコルプ リズムで觀测し放がら金屬表涌からの反射光が完全に平 面偏光となるまで偏光子ニコルプリズムを趜搏する。と の反射光が平面倔光となるのは入射光の偏光面が入射面 に平行であるか，或は太射而に西直であるかである。故

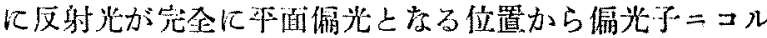
プリズムを更に $45^{\circ}$ 傾ける上，入射光り倡光面は入射面

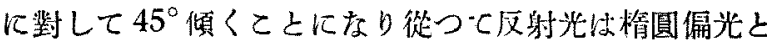
なる。站に於て四分つ一波舆板を入れて，てれを反射光

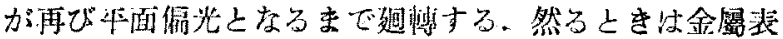
面で反射したために生じた㤚圆偏光を呀分の一波長板で 打ち消さしたわけである。若し反射光が本面偏光であり，
こ就を大射面に平行及びそれに垂直な平面內に偏れる二 つの平面偏光よりなるものとし，この三つの部分平面偏 光の强さが相等しい即ち金置表面に於けるこの部分平 面偏光に對する吸收が相等しい之すれば检光子ニコルブ リズムを入射面に對して傾むくべき觕 $\theta_{p}$ は偏光子 $=$ こ プリズム及び四分の一波板の位置から直ちに計算し得 うわけである。實際には上の心つの部分平面偏光の强さ は相等しくないから检光子二コルプリズムを角 $\theta_{p}$ と異

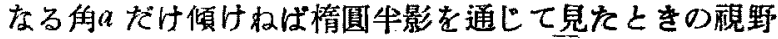
の右右兩牛忙同一の明るさにならない．乙の角 $a$ 吉检光 子の度盛り板から讀めば，上の二つの部分平面偏光の强 さの比故 $\psi$ は $\quad \tan \psi=\frac{\tan \theta_{p}}{\tan a}$

となることを容易く證明し得る. 又位相の差しは偏光 子ニコルプリズムに對する四分の一波長板の傾きからわ 加方. 從つて前の公式 (A) と (B) とから乙の金虽表面に 於ける光の屈折率 $n$ 及び吸收係數火が求められること になる、トロンスタット(3) は後にこの方法を少しく改め て，入射光を上の如く平面偏光としその偏光面を入射面 に街して $45^{\circ}$ に倾けを後四分の一波长板を任意の角 $Q$ に 固定し，棈蒷坐影及び檢光子ニコルプリズムで觀測しな がら反射光が平面偏光となるまで偏光子ニコルプリズム を呬轉するやうにした。との特の偏光子=コルプリズム の位置をPとすると

$$
\begin{aligned}
& \sin \Delta=(\sin 2 Q P, \sin \delta) / \sin 2 \theta . \\
& \tan \psi=\frac{\tan \theta}{\tan A}
\end{aligned}
$$

によりて位相の差, 及び二つの部分偏光の强さの比 $\tan \psi$ が求まる.但しA は检光子=コルプリズムの固定角, $\theta$ は $\cos 2 \theta=\cos P Q \cos 2 Q+\sin 2 P Q \sin 2 Q \sin \delta$ で與へられ るは四分の一波長板による位相の差であるか ら多くの場合に $\delta=90^{\circ}$ と見てよい. 向在らょンターボッ トン(4) (A. B. Winterbottom) bとのトロンスタットの 装犆と全く同樣な偏光分光器を作つた.

以上迅べを方法に上りて金閩表面の光學常數即ち厘折 率 $(n)$ 吸收係數 $(\kappa)$ 及び 反射率 $(R)$ 老求め得る。乙の試 料金風の表面に被膜が生じた場合にはその被膜がたとへ 逵明な極めて薄いるのでも入射面に平行及びそれに垂直 な二つの部分偏光の强さり比 $\tan \psi$ 及び位相の差

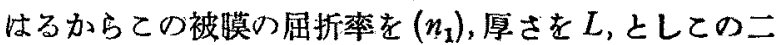
D0部分平面偏光の强さの比が $\tan \psi$ 上り $\tan \bar{\psi}$ に，位

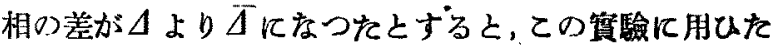
光の波長を $\lambda$ として

$\Delta-\bar{\Delta}=-\frac{4 \pi L}{\lambda} \frac{\cos \phi \sin ^{2} \varphi}{\left(\cos ^{2} \phi-a\right)+a^{2}}\left(1-\frac{1}{n^{2}{ }_{1}}\right)\left(\cos ^{2} \phi-a\right)$,

(3) P. Tronstad. Journ. Sci. Instrum., 11 (1934), 144. 
及び

$$
\begin{aligned}
2(\psi-\bar{\psi})=\frac{4 \pi L}{\lambda} \sin 2 \bar{\psi} \frac{a^{\prime} \cos \varphi \sin ^{2} \varphi}{\left(\cos ^{2} \phi-a\right)^{2}+a^{2}} \\
\\
\left(1-n_{1}^{2} \cos ^{2} \varphi\right)\left(1-\frac{1}{n_{1}^{2}}\right) .
\end{aligned}
$$

の關保が成り立つ. 站に $\varphi$ は入射角であり， $a$ と $a^{\prime}$ とは

$$
a=\frac{1-\kappa^{2}}{n^{2}\left(1+\kappa^{2}\right)^{2}}, \quad a^{\prime}=\frac{2 \kappa^{2}}{n^{2}\left(1+\kappa^{2}\right)^{2}}
$$

である.故に被膜の生ぜない金屬表面の $\tan \psi$ 及びムと 被膜を生じた後の $\tan \bar{\psi}$ 及び さ $L$ 及びそれの屈折率 $n_{1}$ が上の關係式から求められる. 筫祭に上式は簡單ではないから，てれより $L$ 及び $n_{1}$ 求めることは甚で煩雜ではあるが，光の干涉による方法 が用ひ得られない程度に薄い被膜又は着色せる表面被膜 の厚さ及び屈折本孝求如得る點几於て特几興味が深い。

ローリーの用ひを裝置をその原理に於てはトロンス タフトの裝置と同一である，垖ち第 2 回化示す如く分光

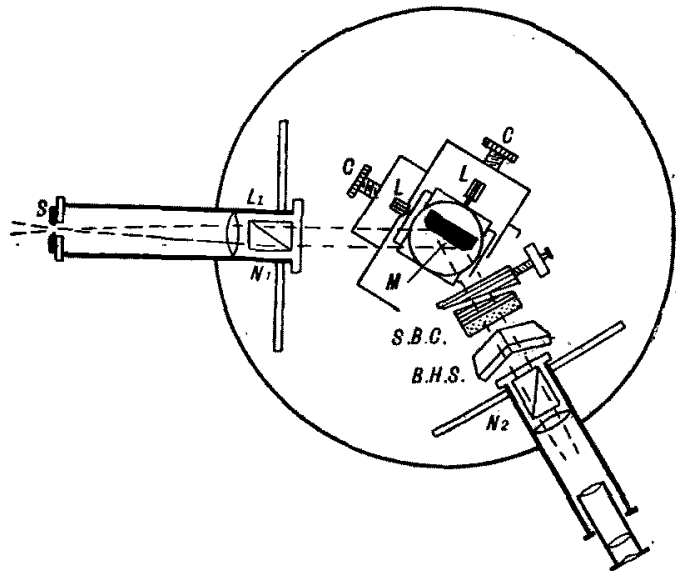

第 2 涡

器で單色にした光を第二の分光器の細㩐.上に焦點を結 ばせ、コリォーターレンズ $\mathrm{L}_{1}$ で平行光束にし偏光子二コ ルプリズム $\mathrm{N}_{1}$ で平面偏光にし，陚料金屬 Mに入射させ， その反射光をソライューパビネの調整子(Soleil-Babinet Compensater) S. B.C 及び棈圆牛影裝置 B. H. S 专通過 させを後检光子ニコルプリズム $\mathrm{N}_{2}$ 及び瑟遠籍で觀测す る.即ちトロンスタットの裴置では四分の一波長板が珷 料金屬の前にあつたが，ての裝置では四分の一波長板の 代りにそれと同一の作用をするンライューバピネーの調

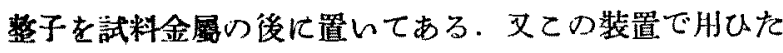
偨圆本影装置はケント (C, V. Kent) ${ }^{(5)}$ の考案した所謂バ

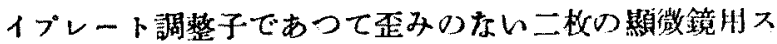
ライドの各:の二邊寺磨り合せて角 $120^{\circ}$ の傾を度す やうに接を合せたものである。この接を゙目削ち网板の其 通の邊を检光子ニコルプリースムの偏光面に垂㨁となるゃ
5に且つその雨板がそれに入射する光に龁して相等しい 角をなすやらに調整した後，检光子ニコルプリズムと共 几䢙轉し得るゃらにした日のである。ローリーのての裝 置もその原理几於てトロンスタットの裝置と同一である から，上に述べトロンスタットの場合と全く同樣な調整 をして $\tan \psi$ 及び $\Delta$ を觀測し得る。

上に述べを如く金圈表面の光學常數の测定は反射光て ある楕圆偏光を互に直角な平面內に偏れる二つの部分平 面偏光と考へての部分偏光の間の强さの此と位相の差と を测定するてとである。てのために四分の一波長板又は ベビネーゾライ二の調整子によりてての二つの部分平面 偏光の間の位相の差を 0 又は $\pi$ として反射光老平面偏 光として檢光子ニコルプリズムによりて觀測する。從つ て测定の精度は棈圆偏光が正しく平面偏光となれりや否 や關係する．乙の光が正しく本面偏光であることを確 めるために、トロンスタット ${ }^{(3)}$ は新らしい棈圆本影裝置 を考案して用ひてるる.

\section{金虽研磨表面の:光䁷常数}

金屬表面の光に對する屈折率の測定は凮にドルューデ に先だち1880〜1890年の頃クント(Kundt)フリューガー (Pfluger) シェア(Shea) デュボア及びルーベンス(DuBois and Rubens)等によりて試みられた。てれらは何れる硝 子のやらな普通の透明體に於けると同樣に薄的金䐂板で つくつを極めて小さい頂角のプリズムで光を届折させる 方法を角びを.このブリズムの小さい項角を精密に測定

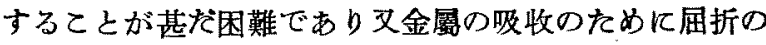
後に於ける光の强さは甚を゙弱くなるため精密な結果は得 られなからた・ドルュー゙が前節に述べた如くての光學常 數の敗定方法に一大改良を加へたが金風の表面を研磨す る方法及び研磨の程度の相違に上り，又研磨の後に生ず る表面被膜の種類及びその厚さの相違によりてその测定 值が區そとなつて正しい數值が見出だされなかつた。、口 ーリー ${ }^{(6)}$ は從來の賽驗文献を檢討した後研磨の間に用ひ た研磨劑が磨き.上げた後微量でも表面儿殘つて金圂の純 度を損し，そのために光學常数化影響を及社さないか，又 表面の研磨仩上げの程度により，且つ表面に生ずる被瞙 の厚さによりて光學常數が如何や5に變るかの基礎問題 を先づ研究しょうと試みを、研究の裝置は前に述べた口 一リ一の考䓩によるものであり, 試料としては比較的に 純度の高きこと，研磨の容易なとと，又表面に生ずる酸化

(4) A. B. Winterbottom, Journ. Sci. Instrum., 14 (1937), 203.

(5) C. V. Kent. Phy. Rev., 14(1919), 459.

(6) H. Lowry, H. Wilkison, D. L. Smare, Phil. Mag., 22 (1936), 769. 
被膜当徐々に生じ時間の經過と共几厚くなること考考虑 して先づ銅を選んだ，先づ純度の高い電解銅を真空內で

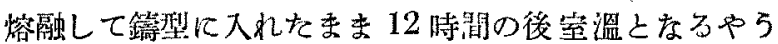
に徐々に冷却する。乙れを 1 时平力の表面に四りたる後

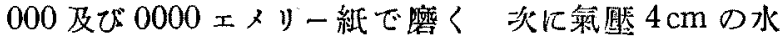
䕀內で $700^{\circ}$ スインダクションヒーターで熱し 12 時間燒 鈍しする. 然る後 0000 エメリ一紙にて極めて俓く磨り， 濨つたシルビットにアルミナメはマグネシアを水に混じ

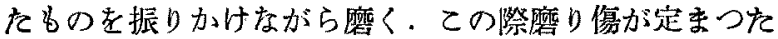
方向のみに生ぜないやらに試料を䋓えず䢙㙛しながら磨

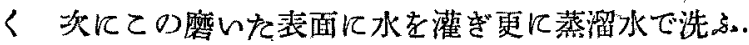
てれを輕くェッチして磨きの間に生じた表面の非結晶留 バイルビー厴を取り去り石琋水で洗ひ，ダリース等を除 くをめアルコール，四監化炭素で潅ぎ直接手に觸れず 清淨な滤紙で包んで測定裝置の試料支持臺の上に載せ た後その前面の溜紨を去つて測起を始める。てのやら な研磨を施しを試料をローリーは輕く㓺いた銅の表面 と名づけた.てれに對して上の燒鈍しの後、ナルミナ又 はマダネシアで磨く代りに硬い銓の研磨面を壓しつけ て表面に出凸のない面に任上げをるのを强く喽いた面 と名づけた。

ての二種類の方法で研譄した銅について光學常數を測 定して第 1 表に示す如を絬果を得た。

\section{第 1 趇銅}

\begin{tabular}{|c|c|c|c|c|}
\hline & & 屈折率 ${ }^{\prime}(n)$ & 㔭收你媻 $(K)$ & 反射率 $(R)$ \\
\hline \multirow{2}{*}{ 輕䂰 跣 } & I & 0.500 & $2 \cdot 33$ & 0.737: \\
\hline & II & 0.539 & $2 \cdot 88$ & 0.798 \\
\hline \multirow{2}{*}{ 强 㸴 磨 } & I & 0.556 & $2 \cdot 53$ & 0.701 \\
\hline & II & 0.590 & $2 \cdot 23$ & 0.637 \\
\hline
\end{tabular}

てれによると强く研礬すると，屈折率は大きくなり，吸收 係數と反射率とは減少する，金屬表面を鏡として琱しる 場合に强く磨くよりも偨く磨いた場合が光の反射の量の

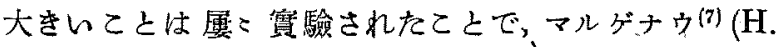
Margenau) が銀の表面の堇外線に對する反射率の测定 も同樣の結果となつてみる。銀は可塑性の變形が容易で あり，参激に表面が酸化その他の化學變化を受けず，且つ

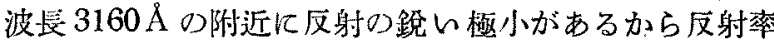
の變化はこの检小の附近の部分で特に蹬敏に觀测され得 るわけである。マルゲナりは装面者細かなエメリ一紙で

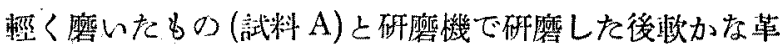
で擦り上げたものと(試料B)をつくつた。肉继で見る

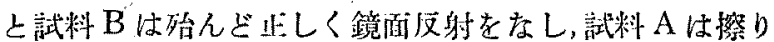

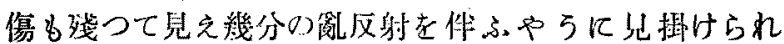

(7) H. Margenau, Phys. Rev., 33 (1929), 1035.
た. 筫際に波長 $2800 \mathrm{~A}$ 乃至 $3400 \mathrm{~A}$ の䊈图での反射率を 测起して見ると，桱く磨いた試料 Aの反射率が强く磨い た試料 B の反射率よ 的 $12 \sim 13 \%$ 多かつた.

ヒに述べたローリーの゙銅につんての筫驗の絬果は研磨 の方法並に程度によりて光學常數が巽なるてとを示した ものである。ローリーはこの事實を研磨のために生じた 裴面の非結晶質即ちバィルビー㸴の厚さによる8のと考 へた. 師ち從來測定された金屬表面の光學常數はこのバ イルビー層の常數であつて，金䐂そのものの值ではなん． 器栈的に装面を研碚するならばこのバイルビー層の成生 は避けられないし，然か子研磨の方法，その程度によのて その厚さが相晎なり，自目に調節するととが不可能であ ろために金屬表面の光學常數が區々に测定されて統一さ

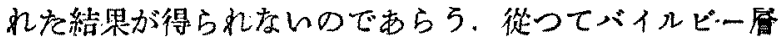
の影響を受けず金屬の寡の光學常數を知るには他の方法

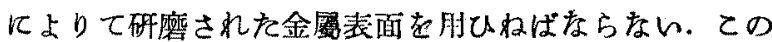

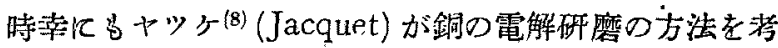

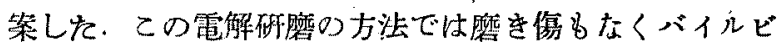
一厤もはい清浮度表面が得られるのでローリーはこの方

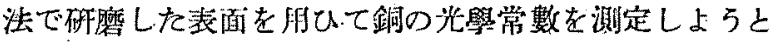
試外を。它とより電解研磨を行ふとしても先づ豫め試料 を本滑にして置く必要がある。この初めの器栈的研磨印 ち常溫加工のためにバイルビー層は出東てはるるが電解

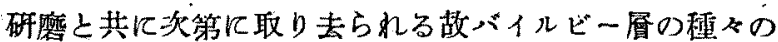
厚さに對して光學常数が如何やらに戀じ行くかを知り得 るかけである。

ローリーは電解鉰支頁空熔融して 1 时平方の裴面をつ

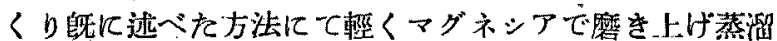
水洗淨を行つた後清淨な㴓紙上に置き直接手に䚡れずそ の表面をアルコール洗淨を行つた後電解槽の陽極とした。 電解液としては比重 $1.3 \sim 1.4 の$ オル燐酸溶液を用ひ， 陰極としては $8 \times 6 \mathrm{~cm}$ の熦い銅板を版ひた。電極間の距

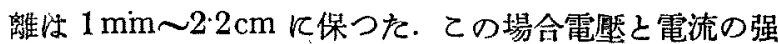

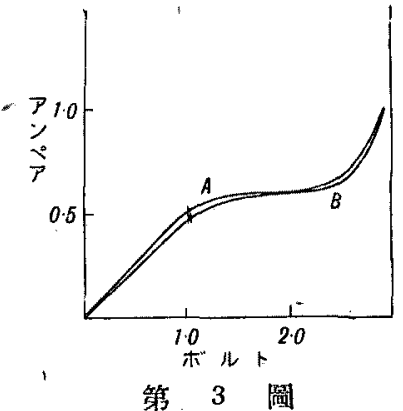
さとの閏係は第 3 圖に示 寸如人, $\mathrm{A}$ 點 (電壓 1.2 1.4 ボルト)上B 點 (電盟 $2 \cdot 0 \sim 2 \cdot 4$ ボルト)の間は 電流の强さが大體一定 で0.5〜0.7アンペアの程 度であり，電解研磨が行 はれうるのはての電壓電流 の强さがこの A B 三點 で示される筙圍であつた，電壓が A 點より低いと陽 極エッチングが起るから電隼を速かに睤しててれを避け

(8) P. A. Jácquet, Nature, 135 (1935), 1076; Trans; Electrochem Soc., 69 (1936), 629. 
壮ならない、及 B 點より高いと酸素氣泡を生ずるか らての電㻺以上にならぬやらに絶えず調節を要する．嘪 祭には電壓 1.95〜2:0ボルト電流の强さ $0.65 \sim 0.70$ ア ンペフの封最も良好な結果を得を，電嶎電流の强さの調 節の間に時としては等い薄い被膜を生ずることがあるが 手早く A B の間の電献一電流の强さとすると汛速に取り 去られる。

一かくして電解の时間と光學常數との關係を見るため そ，山と位相の差 $\Delta$ と測定すると第 4 圖及び第 5 圆の

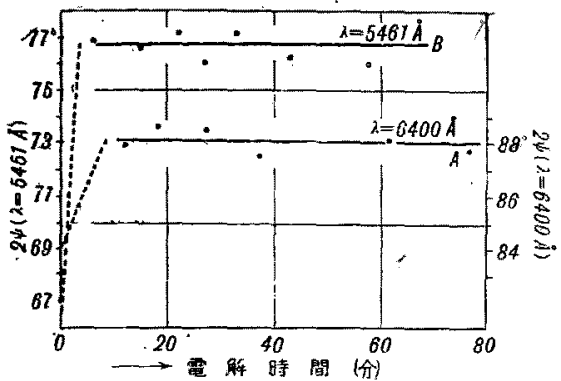

第 4 團

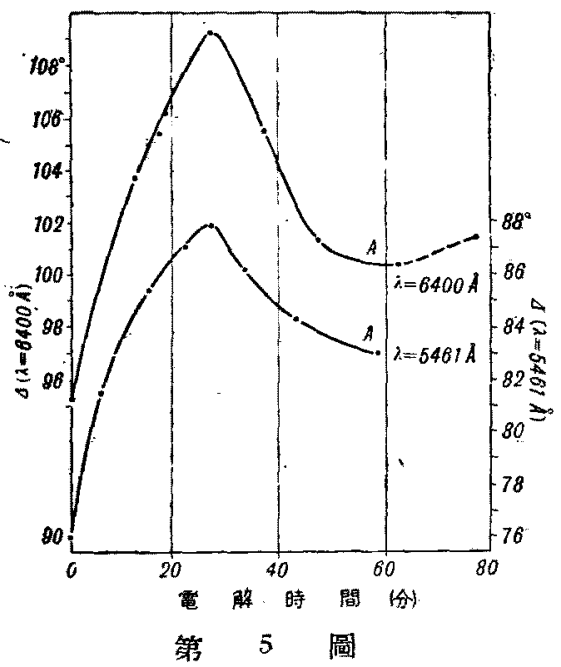

如結果にな る. 臫5 $2 \psi$ は初めの約 5 分閒江急激に 㯒加して啳一 定になり， は電解特閒之 其に次第に霄 ᄂ約 $26 \sim 27$ 分氏て極大之 なつそ後減少 する。この電 解儿於て陽極 の表面の厚

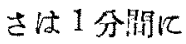
$478 \times 10^{-7} \mathrm{~cm}$ だけ電解され ると推测され るから最初の 5 分闃の電解 で表面のバイ ルビー燐は取 り去られ，之 の後は $2 \psi$ 少

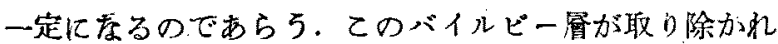
てもその直下にある結晶體は份压器栈的研碳のために結 晶の大きさ，その位置は想論不揃ではるがてれは $2 \psi に$ は影響せないと若へら北々、この表面の結晶の大きさ及 ひ位置の不規则性が取除か礼る厚さ㤌 $\Delta$ が極大となる $27 \times 478 \times 10^{-7}=0.00129 \mathrm{~cm}$ 位であら5．强く研磨した 試料ではての厚さが $0.0029 \mathrm{~cm}$ と高つたもりもあつた。 ムがこの極大過きて再び減少するのは電解のために印 つて表面が傷められるのでは存いかとる落へられるが 2廿が一定であるから，恐らく他の原因に基くものであら 5. 研磨のために起るバイルビー樰及び結昆の不規则な 配置を示す厚さについてのローリーのこの研究の絬框は 電子趈折の方法でリース ${ }^{(9)}($ C.S. Lees $)$ ポプキン ${ }^{(10)}(\mathrm{H}$.
G. Hopkins)等が得た值より大きい. 郎ちてれらの研究 者つ金につんての實驗では研磨表面の電子の䢙折像は最 環ですり，陰極スパッターの方法で表面の層を約 $10 \mathrm{~A}$ 取 り去ると結晶の種くの方向を示才鮮明な環となり $30 \mathrm{~A}$ を去れば環の分離度を堌して結晶が稍に大きくなるてと を示し $500 \mathrm{~A}$ を越えると，普通の鮮銑な環となつて研磨

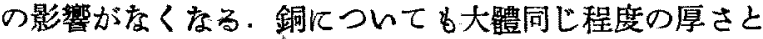
見てよん，もとよりこのバイルビ一首及び結晶の不規则

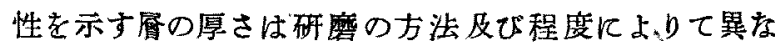
るけれども，電子䢙折の方法で推测されるよりる，ての 光學常嘍測定の方法で求められる值が遙か炕大きくな る理由に就ては何等の馀明も加へられてるなんのは遗 䜗でする。

かやら江電解研磨の進さに從ひ最初の器械的研磨で生 ビを表面の㕌が取除かれ 24 及び $\Delta$ 值が上の第 4 圆及 び第 5 圆に示す幻く變はつて承る。筮つて銅の届折率 $(n)$, 吸收係數 $(K)$ 及び反射率 $(R)$ は第 6 團の如く計算さ

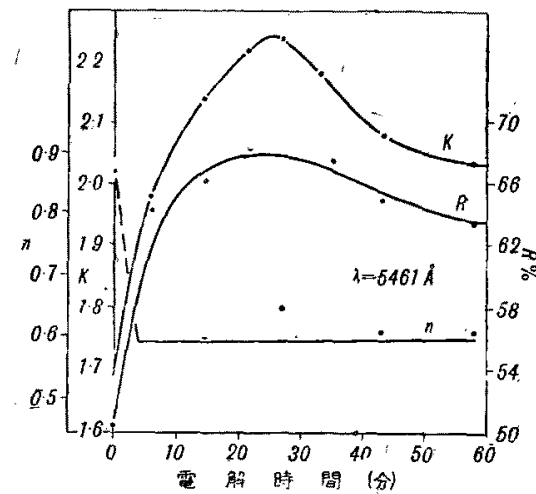

第 6 嫡

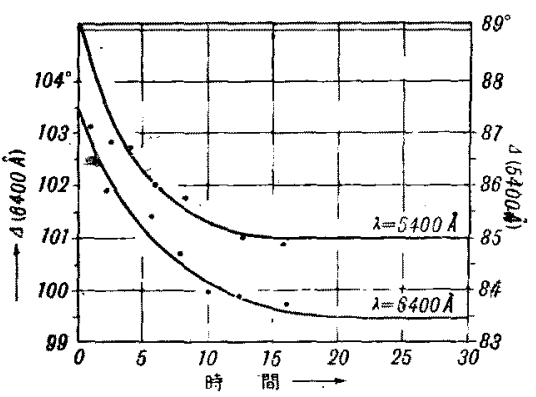

第 7 圆
れる. 又一定 時間電解表面 研磨の後大氧 中几置き時間 の經過江件子 て 及で $2 \psi$ が如何や5に 變はるかを觀 测すると $2 \psi$ は㱠んど變化 世をかつたが $\Delta$ 住茅 7 圖の 如き變化を示 した. 師ち は最初の數特 間の閶に急激 学減少走し $13 \sim 14$ 時間 の後には時間 軸に路して平 行汇一定倠 となる。乙礼によると，銅の素面に生ずる酸化物被膜

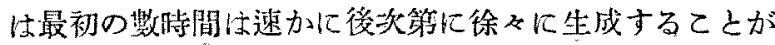
制る. 從つて酸化物被膜のために屈折亲 $(n)$ 吸收係数

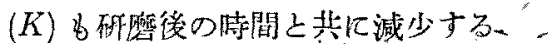

ローリー (11) は炏に銅ーニッケル合金系の光學管数の测

(9) C. S. Lees, Trans. Faraday Soc., 31(1935), 1102.

(10) H. G. Hopkins, Trans. Faraday Sọc., 31 (1935), 1095

(11) H. Lowry, Phil. Mag., 20 (1935), 390 
定をも試みてわる。この合金系はその組成を通じて固溶 體ですり速緮的に組織を變ずる简單な二元合金である。 固溶體又は化合物は一般にその性質に於て純金遏と同椂

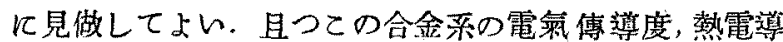
度,熱電動力等はその組織に對して簡單ではないが連縝 して戀ずる，その硬さも办組成と共に連緢して變ずるか ら同樣な表面研磨をしても表面の碷鿬の程度は同一でな 々．それ故表面の研既による光學常數の變はりを間接に 知るには甚だ適當る試料である. 又この合金系の結晶格 子は銅, ニッケルを初めての合金系の全部に亘つて何れ も面心立方格子である・グラーバー(14)の單結晶の磍乫 による上，亞鉛，、ダネシウムの如き稠密格子の結晶では 結晶蟿が反射面に平行でするか或は垂直でするかにより て光學常數は相等しくなん，ての合金系の結晶格子住何 れる同一であるから桶密格子の結晶の場合のやうな複雜 にならない便宜がする。試料は前の銅の場合上同樣に種 種の組成につくつた銅ーニッケル合金を真室揢融し，成形 して表面を 0000 エメリ一紨で磨き真空內で $1100^{\circ}$; 亿熱 しそれぞれ 17 時間， 30 特間, 50 時間の後室溫となるや

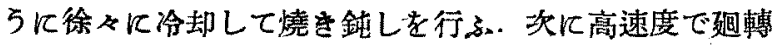
せる具鍮板上に張つたシルペット布上にマダネシア微粉 上蒸溜水とのペーストを染つたものの上柾く塺しつけ

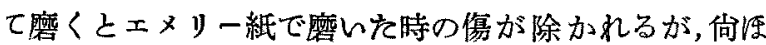
極めて徽細なるマグネシア䂟さの跡が殘る。てれを溥い 監化鐵の溶液で洗ふと表面の非結晶質が除かれて結晶の 境界が見える。時として非結晶質の下゙に何ほエメリーの 磨を賃が現はれることがある。この場合には更に上の研 磨を繰返す。この磨きの程度で止めたもの索試料の(1) とする。次にマグネシアを水中で层落し 5 分の後晌原沈 降せをいるの老布上にとつて趣轉票鍮板上に張り，この

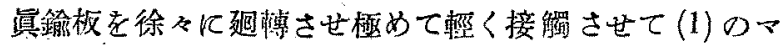
グネシアの磁を傷が見えなくなるまで挽いて監化鐵溶液

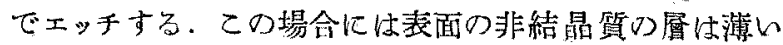
から稀欂な㫌化鐵溶液でエッチしてょい。この磨さ上げ をしたるのを試料の(2)上する，更に磨きす程度を進め

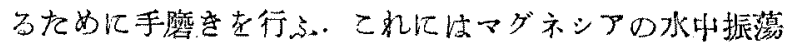
後 10 分後にまだ沈降せないものを仍にとりこれを硝子

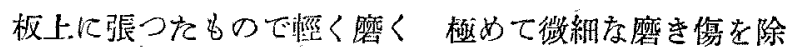
くのに苦心をしをがトのマダネシア䍀粉のペーストを指 先に㾞つて櫭く磨いて甚た有効であつた，て秃を試料の （3）上する. 何れの試料でもダリースの痕跡を去るため にはアルコールで先つを後水在注いで洗ふ..この三種類 の試料につんて光學常數考测定すると何れの組成の会金 でも磨きの程度が進むに從い屈折率も吸收係数も亦反射 率当共に大きくなる。この合金采に對しては涙だ電解碑 磨のカ法がかかつてわないから以上記截した方法以上の
磁き上げを試みなかつたが，ての結果から光學常數の値 てよりてての合金系の表面磨さ上げの程度が制断される とローリーは迅へててる.かく充分によく磨を上げを試

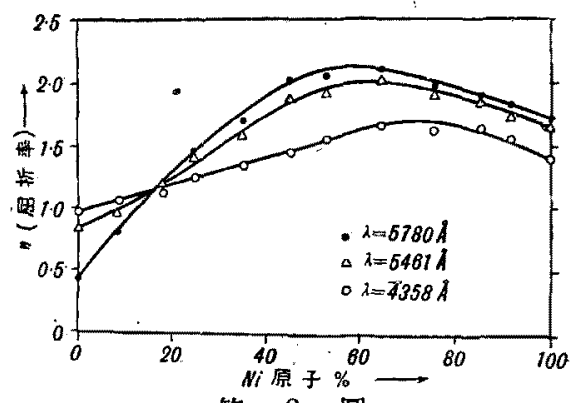

第 8 圖
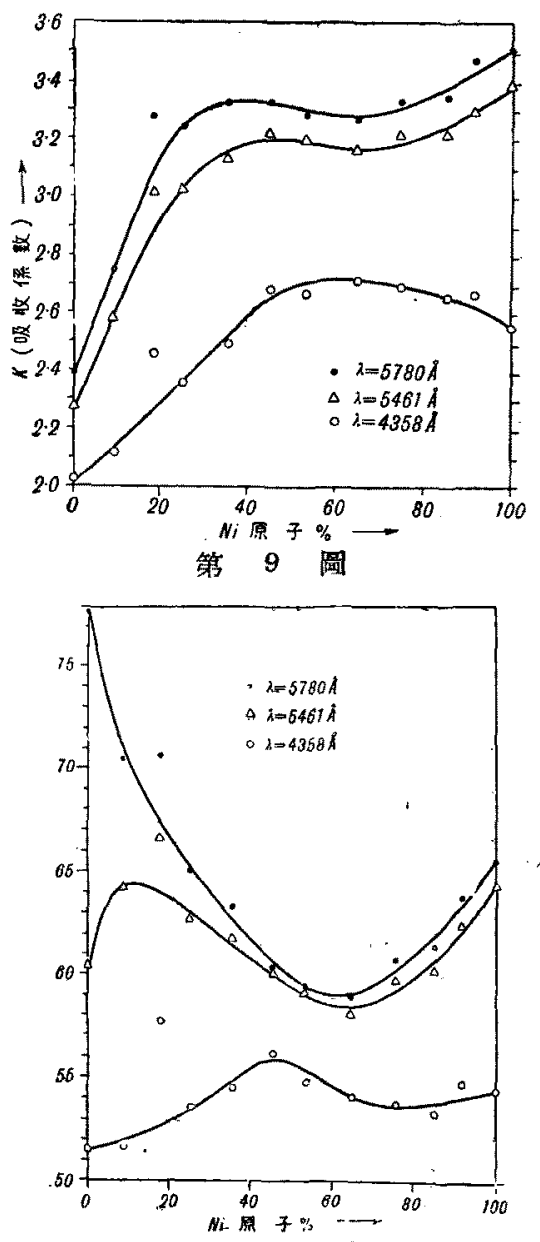

第 10 圆
料の (3) 亿つ 几ての光學常

數とその組成 との關係は第 8〜10国の如 くになつた. 制ちこれらの 光學常數はそ の組成により て連續して變 ナ゙るけれどる この間の關係 は簡單ではな n.

ロ 一リー・ウ キルキンスン 及びスメ (12) $^{(12}$ は次任銅一亞 鉊合金系の光 學常數の測定 を陚みた。と の合金系は純 銅加 $53 \%$ Znまで郎ち $\alpha$ 相の終りま で所謂真鍮色 を呈し46.5 $49 \% \mathrm{Zn} \infty \beta$ 相で再び銅赤 色儿60〜69\%。 Znの $\gamma$ 相で 銀色と交子。 かやろに組織 と共に表面色 が著るしく戀 化するにつれて光學常数が如何わうに變化するかは甚た 興味の深々問題である。試料としては電解銅と亞欽とを 第2 表に示す如を組成に混じてて真空揢融して鋀物とし銅 ーニッケル系の場合の如く成形し燒鈍する。

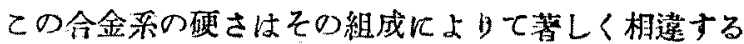
から各にの北料を相等しい程度に磨き.たげることは困難

(12) H. Lowry, H. Wilkinson, D. L. Smare, Proc. Phys. Soc., 49 (1937), 345. 
である.その上銅一ニッケル采合金に比してての合金系は 一般に軟かで磨き傷を生じ易く表面の污れが見出だし難 々. 實際に表面に微細度磨き傷があるとき特にこの磨き 侮が平行な場合にはこれに入射した光を偏らせる作用か゚ 第 $\quad 2$ 表

\begin{tabular}{c|c|c|c|c|c|c|c}
\hline \hline 試料番號 & 1 & 2 & 3 & 4 & 5 & 6 & 7 \\
\hline 相 & $\alpha$ & $\alpha$ & $a$ & $\alpha$ & $\alpha$ & $\beta$ & $\gamma$ \\
茞 鉛 $\%$ & $6 \cdot 58$ & $8 \cdot 91$ & $12 \cdot 40$ & $19 \cdot 40$ & $25 \cdot 39$ & $47 \cdot 15$ & $67 \cdot 25$ \\
釾 $\%$ & $93 \cdot 42$ & $91 \cdot 09$ & $87 \cdot 60$ & $80 \cdot 60$ & $74 \cdot 61$ & $52 \cdot 85$ & $32 \cdot 75$ \\
\hline
\end{tabular}

あるから注意して取除かねばならなん、ローリ一等はこ の合金系試料の表面研磨を種々の方法で陚みたが何れる 满足な結果は得られなかつた，即ちての合金系の試料表
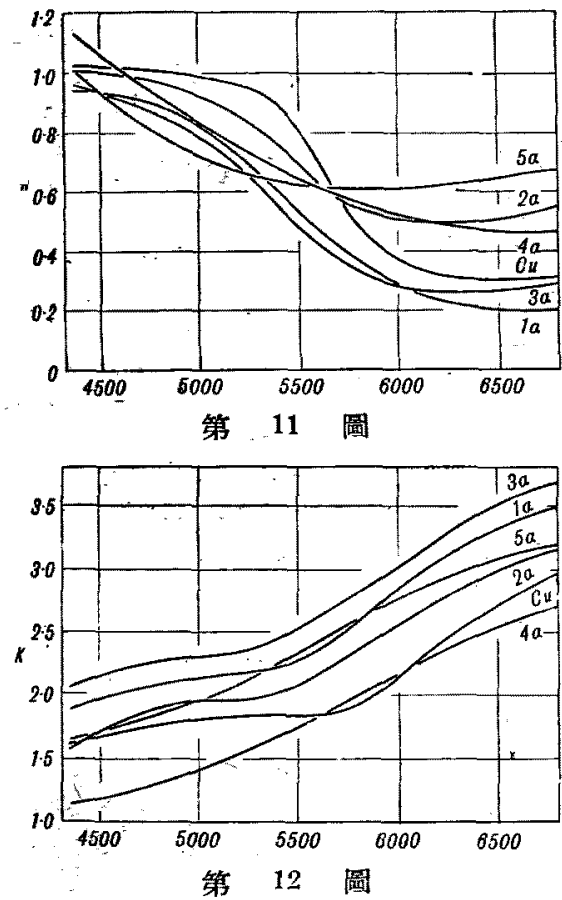

面を硆子の表 面のやうに磨 き上げること は不可能であ つを. 從つて 止むを得ずて の各:の試料 を鉛の中に像 嵌して同時に 研磨し何れの 試料的同一 の表面處理老 行つて光學常 數 $n, \kappa$ 孝测 定して第 11 , 12 圖行示す やらな結果を 得た. 加や5 に總ての蓶料

の表面责同一に處理したが陚料によりて器械的性質が異 なるからそれぞれの試料表面が受けた常溫加工の程度は 相等しくないのでこの結果の意味る更に檢討されねばな 交々。

\section{金牁單結晶の䢃開面の光學常數}

前節に記述した金屬り研磨表面の光學常數の测定の結 果から研磨は決して簡單な物理操作ではなく研磨表面 当 亦清淨な正しん平面ではないことがかかつた。多絬晶金

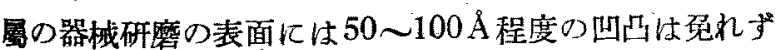
且つ非結晶質表面屏つ生成，研硆劑及びェッチによる化學 督化に件丸表面被膜然のために金屬の表面はその內部之 は組織を異にするのであらち、現在に於て清浮にして且 つ平面に近い表面は單結晶の䢃開面である。トムソン (G.P.Thomson)の電子趣折の實驗によると等䦗面は䢃
開による謔い凹凸は災れないとしても定まつた結晶軸に 教して10'以队に平行である。この金屬の單結晶の䢃開面 の光學常數にはウェルド(13) (R.D.Weld) の考案した結 昆棈圆光計 (Crystelliptometer) 老用ひてダラーバー(14) (M.E. Graber) がマグネシウム及び亞鉛の單結晶につい て测定した結果とデキーケ(15)(G.D.van Dyke)がテル の單結晶儿つレて測定した結果とがある。てれらは何れ も稒密格子型の結晶であるから光の入射面が結晶の主軸 に平行である之き, $\left(n_{1}, \kappa_{1}, R_{1}\right)$ と直角であるとき $\left(n_{2}, \kappa_{2}\right.$, $R_{2}$ ) とによりて同一でなく第 13 圆及で第 14 圖に示す
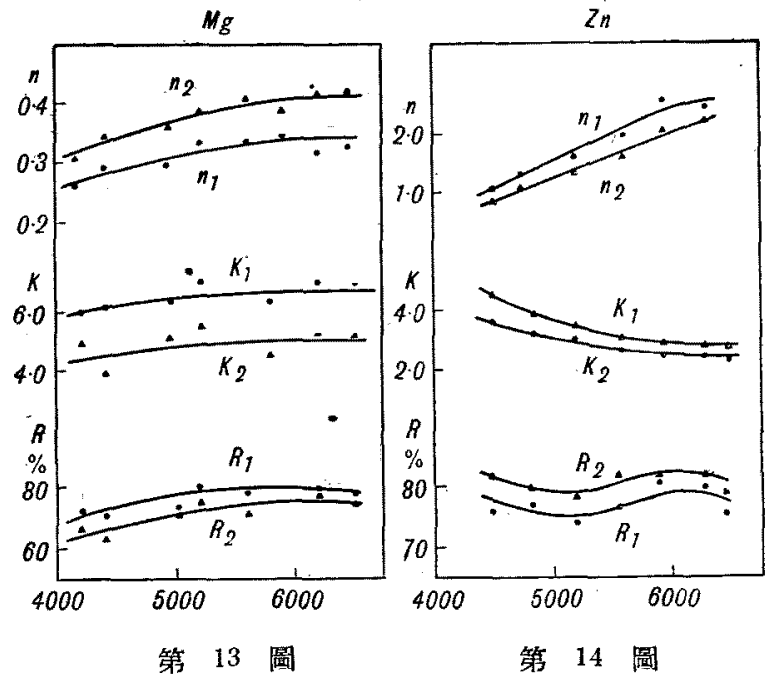

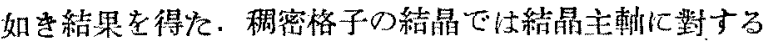
光の入射の方向によりて光學常數を異にすると云るこの 結果はセレシりムについてスキンナー ${ }^{(16)}$ (C.H.Skinner) がバビネーの調整子を用ひて見出たした結果と一致す る.てれに反しマグネシウムの研磨表面についてのド ルューデ及びコブレンツの测定，又丝鉛の研磨表面につ レてのドルューデ、マイヤー，クキンケ等の测定結果は何 れる只一つの光學赏數の值があるばかりで上の如く二つ

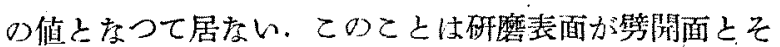

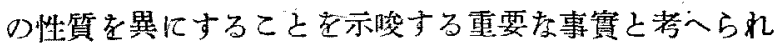
る. 又屈折率は研凮表面に於けると等開面に於けるとに よりて大差は索いが光の吸收係數及び反射率は前の場合 が後の場合よりも大をいととも注意すべきてとであら 5. 他の金屬の單結晶の等開面の光學常數の测定の結果 は未だ公表されてみないやうである。

金虽に限らず總て固體の表面を大氣中で清㴗に保つこ

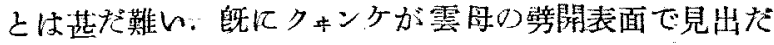

(13) R. D. Weld, Journ. Opt. Soc. Amer., 6(1922), 67.

(14) M. E. Graber, Phys. Rev., 26 (1925), 380.

(15) G. D. Van. Dyke, Journ. Opt. Soc. Amer., 6 (1922), 917.

(16) C. H. Skinner, Phys. Rev., 9 (1917), 148. 
しそ如く固體の表面を大氣中に置くとグリース爿物質の 被脱が生ずる。この被膜は厚さ $10 \AA$ 程度のものではあ ろが表面の性質支著るしく變ぜさせる.マコーレー(17) (Maculay) の研究によるとこのダリース狀物質の被膜は

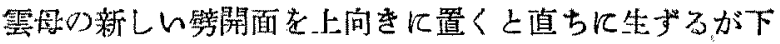

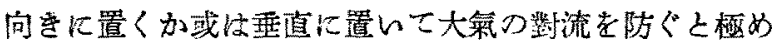
て徐そに生ずる.乙の事筫よりこのグリース狀物筫は大 氣中から㠜着するるのと考へられてるる。金屬表面の電

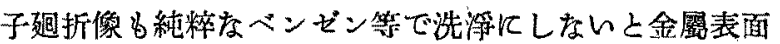
の像とグリース狀物質の迥折像之が同時に表注れて甚方 複雜沈なるとがある。谌だしい場合にはトリラー(18)

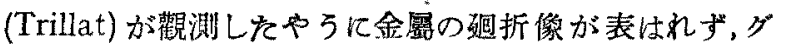
yース状物質の䢙折像のみが見之る場合当ある。研磨の 表面に比して䢃開面は清淨にして正しい平面に近いが䢃

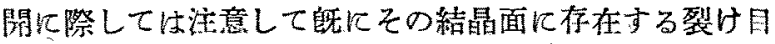
以外心部分上り䢃開するやうに世极ばならない，金屬で は硝子やイオン結晶の場合のやらにその表面に所謂グリ フィスクラック (A. A. Griffith Crack) 時ししてスメーク ルクラック(Smekel Crack とも云る。)\}は存在せないであ らうが向压てれの器械的處理によりて表面に多少の裂り 目はあり得るであらう。かやうな裂け目にはいろいろの

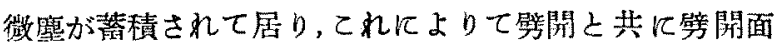
を污す恐れがある，晌瓜この他に大氣中にある固體の表 面には瓦斯の吸着首が出來る金屬で恃特飞酸素の吸着が

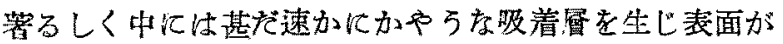
酸化する金屬もある、從つて大氮中几置的金屬の表面

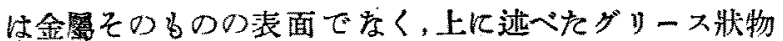

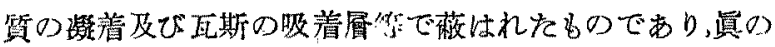
金屬表面Ф光學常數を知るためには真空中で單結晶を䢃 開して大氧に曝さずそのまま真空中で光を入射させてそ の反射光の棈圆性老觀湘する力法が望ましいかけである。

\section{金屬表面の狀癿による光學常數の變化}

金虚の光學常數そのものの測定でなく金屬の表面狀態

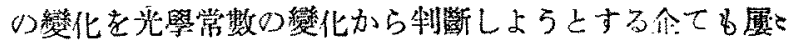

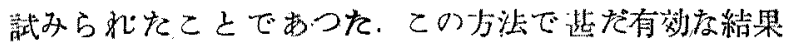

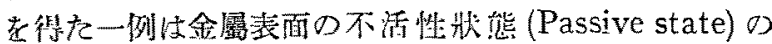

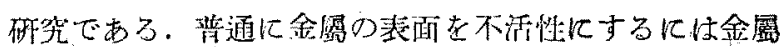

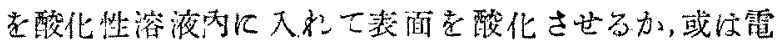

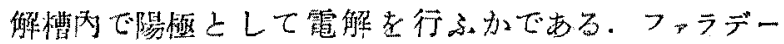

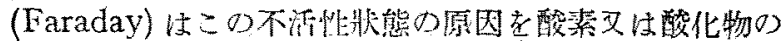
薄被膜によるものとし，ヒットルフ(Hittorf)は金屬の 表面だけでなく內部迄も特殊の化學變化を受りるためと

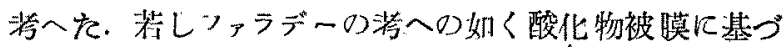

(17) Macaulay, Journ. Techn. Coll Glasgow., 3(1935), 357 (18) J. J. Trillat. Jrans. Faraday Soc., 31 (1935), 1127.
くならば，不活性の狀態に於ての反射率は金風のそれよ

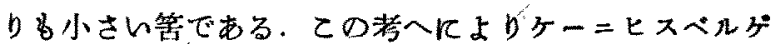
ル及びミューラーは不活性狀態の金噣表面の反射卒の測 定を試みそが筫驗裝置の缺點のために期待した結果が得 られなかつを. 最近行至つて金圈表面の不活性狀態及び

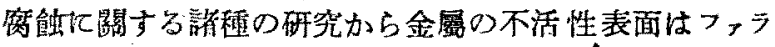
デーの考への如く酸化物被膜で蔽动れて居るととが明か 几なって來た，從つて酸化物被膜の生成發達老乙の光舉 常數の變化から測定しょらと試みられるに至つた。

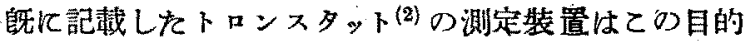
のために考案されそものである。即ちトロンスタタトは

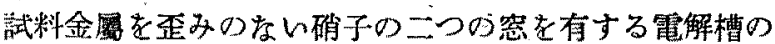
中沉入れ，乙れを陰極とし或は陽極として電解しながら 光學常數老测定するす法を湖てを. 先づ試料の表面を磨 んて，磨き傷酸化物被膜等の全く妾い鏡をつくつた。

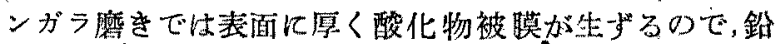

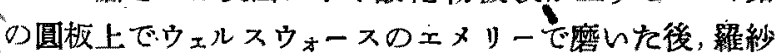

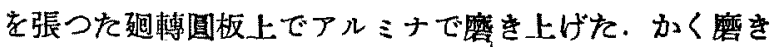

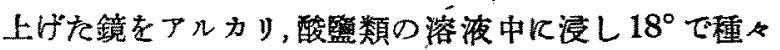

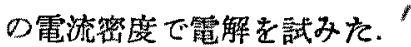

鐵老 $0.5 \mathrm{~N}$. 的 NaOH 及び $1 \mathrm{~N} の \mathrm{Na}_{2} \mathrm{SO}_{4}$ 溶液中で 電解した場合の偏光子ニコルプリズム, 又恬檢光子=コ ルプリズムの峝轉角を示すと第 15 圖の如くになり，こ

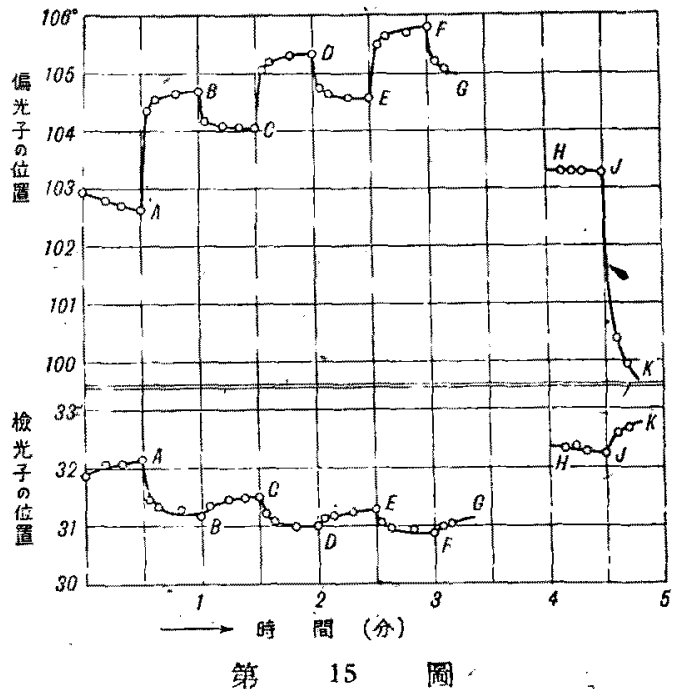

れ上り反射炎の入射面に平行及び垂道学平面內儿偏れる 部分光の强さり比を表はす山及びその間の位相の差ムを

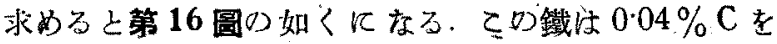
含み電流密度は $0.2 \sim 0 . \overline{4 m ~ A} / \mathrm{cm}^{2}$ であつた。特間の初

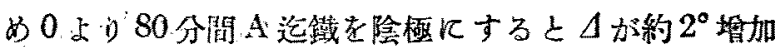
する。との增加をつロインドリッヒ (H. Freundlich); 七っ (G. Patscheke) 及びッォーハー (H. Zocher $)^{(19)}$ は

(19) H. Freundlich, G. Patschelke, H. Zocher, 2. Phys. Chem., 128 (1927), 320, 130 (1927), 289. 
大氣中で研磨の間に生じを酸化物被膜が取除がれるね と說明したががやらな被膜は陰極として處理する場合に

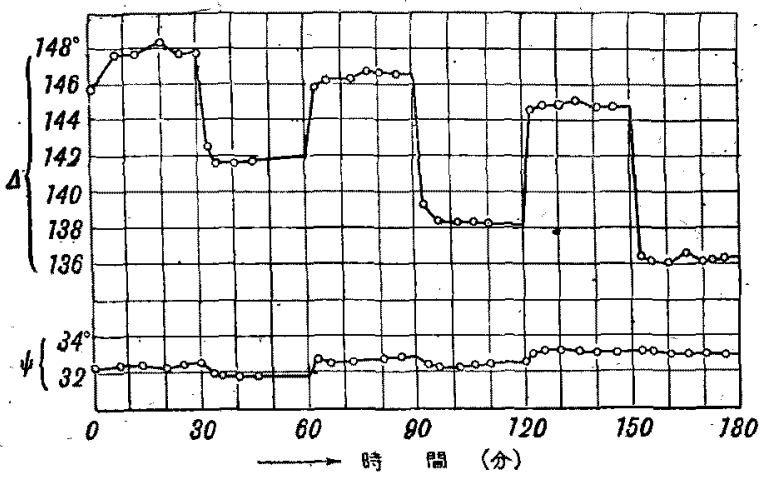

第 16 圖

完全に取除かれること社考人られず，筧ら表面が多孔質

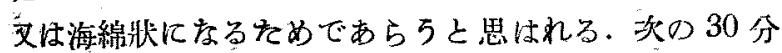
間師ち第 15 圖の Aより B をでを陽極にすると

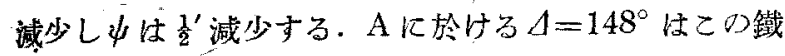

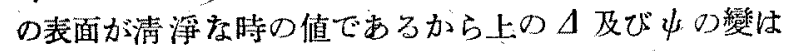
りからこの陽極處理によりて鐵の表面に厚さ約 $30 \mathrm{~A}$ ，屈 折率的 3.0 の被膜が生じたことが称かる.鐵の酸化物の 座折率はクント (Kundt) の賽驗によると 2.6 で上の 3.0 に近いからこの被膜は鐵の不活性狀態ではその表面に酸 化物の被膜が生じ居ることがわかる。陽極にしたままに 置いてる何等の變化は生ぜすいが除極にすると（Bより

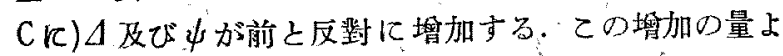
り表面に生じた酸化物被膜の一部分が敢除か狆たことを 示す.次に陽極に(CょりDに)すると酸化物被膜が生じ， 再び陰極に(DよりEK)すればその一部分が取除かれる こ之がわかる.かく試料を交互に陰極陽極にすると酸化

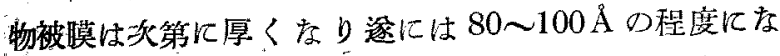
る.この程度の厚さの膜は湴直に照らしたのでは㹣眼で は見えないが，大きい入射角即ち表媔倿するやらに光 を入射させると肉眼でもよく見える。

ニッケルを $0.1 \mathrm{~N} の \mathrm{H}_{2} \mathrm{SO}_{4}$ 及を゙ $0.3 \mathrm{~N} \odot \mathrm{Na}_{2} \mathrm{SO}_{4}$ 中に 浸し，電流密度を $13 \sim 15 \mathrm{~mA} / \mathrm{cm}^{2}$ に保方交互に院極陽 極とした場合に於ける偏光子二コルプリズム及び检光子 ニコルプリスムの廹靕角を测定する上第 17 圖の如くな

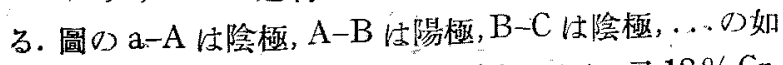
く交立に 15 分宛㓌極陽極とした場合である.又 $18 \% \mathrm{Cr}$,

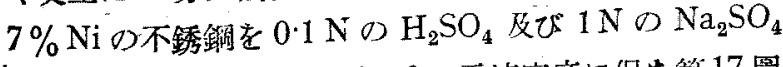
中浸して $0.3 \sim 0.6 \mathrm{~mA} / \mathrm{cm}^{2}$ の電流密度に保古第 17 圖 のD迄酸の溶液のみの中に浸したる後上の溶液中にて30

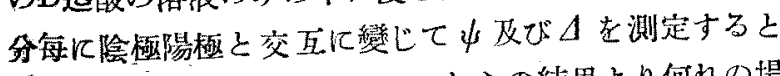
この第 18 圖の如くになる。これらの結果より何れの場 合に金屬の表面儿酸化物被膜を生ずると不活性の状

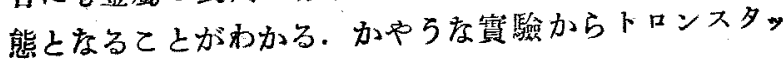

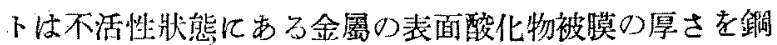
(濃㗂酸中にて處理)的 $100 \mathrm{~A}$ ，銿（アルカリ塎液にて處理）

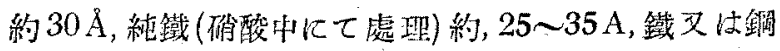

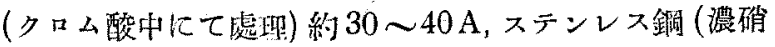

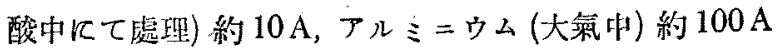
乞推定した.

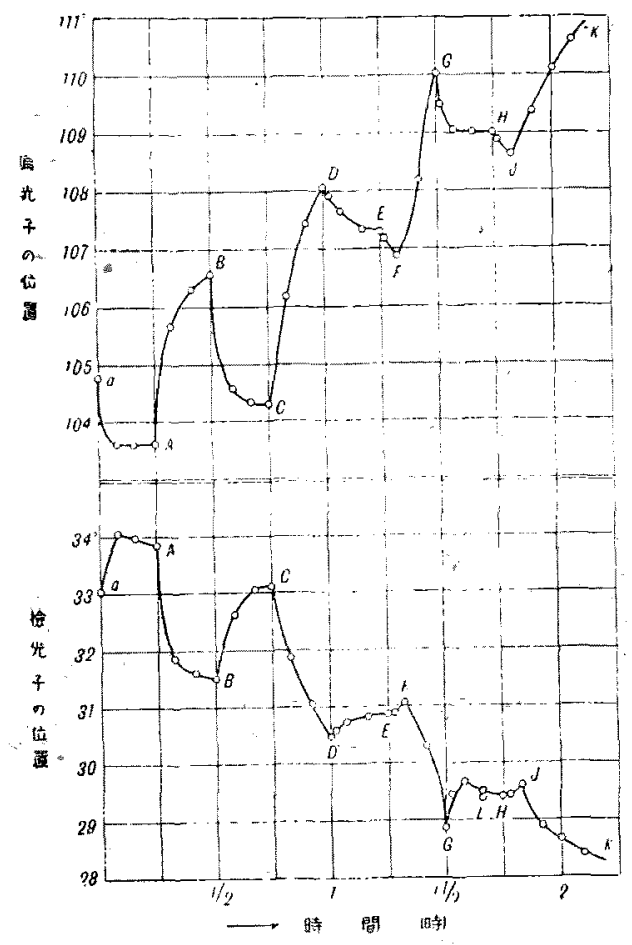

第 17 圖

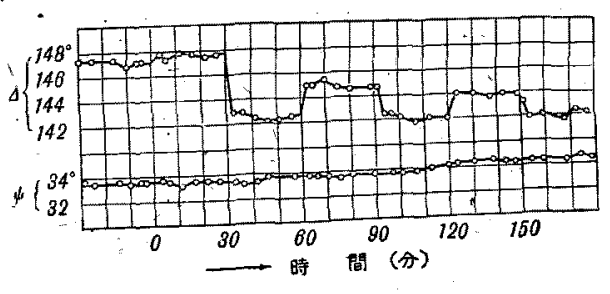

第 18 圆

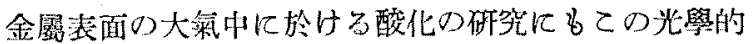
方法が用しられる。フロインドッヒ(H. Freundlich)パ ッンェク(G. Patscheke) 败びツォーハー ${ }^{(19)}$ (H.Zocher)の 研究によると真空中でつくつたカーボニル鐵及び硝子板 上につけた鐵の鏡は $1: 1$ の硝酸溶液で淔ちに溶解する

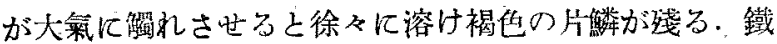

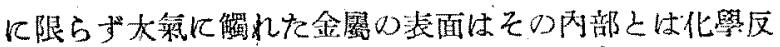
應の帮度が異なるものである・フ、インドリッヒ等はこの 事實を金屬表面に酸化物の被膜が生ずるためであると說 朋した. シッシン(R.Sissingh)及びハーク (20) (J.J.Haak)，

(20) R. Sissingh, J. J. Haak, Proc. Amster., 21(1919), 678.

(21) C. A. Reeser, Physica, 2 (1922), 135: 


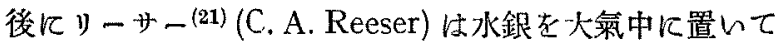
ドルューデの方法で光學常數の變化を测定しその表面に 約 $15 \sim 20 \AA$ 程度の厚さの酸化物被膜が生じ，その以上 の厚され酸化の進さのを防いで居る之結論したが賽驗裝

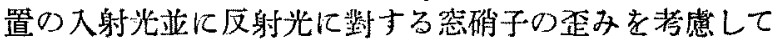
るないからその結果儿は疑閣の稌地があり，向一畨精確 な方法で湘定を繰返す必要がある。トロンスタットは彼

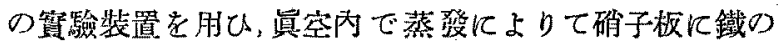
鏡をつくり，眞空內に於ける時と管內に空氣を入れたと

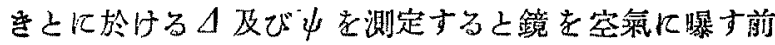

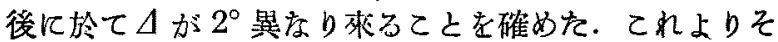
○表面に於战る酸化物被膜の厚さを計算すると約 $10 \AA$ 郎ち陽極處理几上り表面を不活性にした之きの被膜の厚 さの約 $\frac{1}{3}$ なることを確めた．再び空氣を排氣してるム

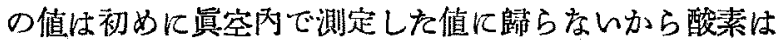
只その表面に咇着してるるのでなく，化學的に酸化物と なれることが推察される。

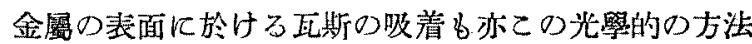

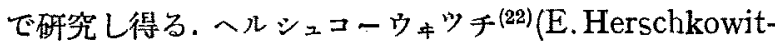

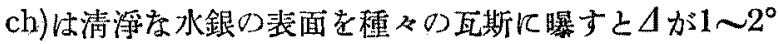
變じ瓦斯を排氣すると若干元の值に近づくことから，瓦 斯の一部分は氷銀と化合し，一部分は表面に吸着せるも のである上結論した．只この際用した瓦斯は純粹ではな く酸素を舍んでわたからちの結果は十分炕信賴されない が吸着の現像に光學的方法を利用したのは興味が深い.

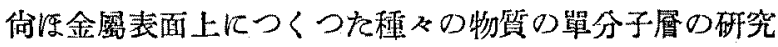
にもこの方法が肘ひられるわりである。

\section{偏光顯微鏡による金屬春面の觀察}

以上は编光によりて金屬表面り光學常數及びその變化 によりて金燭の表面の性質を概觀的に檢べ得ることを 述べたが，装通の小部分間の光學的性質の差違㤢光，顯 微鏡でしらべることが出來るをただての偏光顯微鏡の場 合には檢すべき表面を照らす光は入射角 $0^{\circ}$ の垂淔光上 りその顯微鏡の對物レンズの開口數で起まる極大の入射 角までり間の圆錐光束であり，且つ偏光面当大射面儿對 して雬及り倾を持つ．この入射角の大小入射面に對す

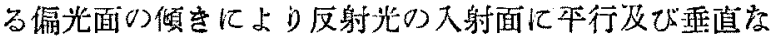
网部分光の强さの比及びその間の位相の差が定まるかけ であるから反射光の偏光性は造だ複雜になる，假りに或 る特别な大射面を若へたとしてるその面內には種々の入 射解及び偏光面の傾を索世る入射光があり，乙の各:

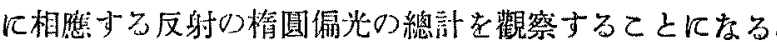

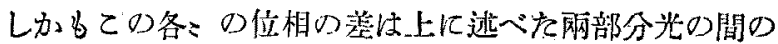

(22) E. Herschkowitch, Ann. Physik., 10 (1931), 993.
相對的の差であつて紹對値でないから計算から全反射光 となる网部分光の間の强さの比を求めることは出來ない． た火゙反射光の偏光性の差違老觀测して，表面の小部分間 の光學的性質の差違を定性的炕區別し得るだけである。

然しながらての偏光顯微鏡で梳普通の顯微鏡よりも金 圈の表面に於ける種なの結晶組織を區別して見やすい: デートン(23) (R. W. Dayton) の研究に゙よると亞鉛, 錫, カ ドミウム,マグネシウムの如き稠密格子の結晶よりなる 金屬の表面を偏光䫏微鏡で觀察すると結晶の位置により て，或る結晶は明るく，或る結晶は喑く，棉々の明るさの 程度の結晶が見える。检光子ニコルを趣轉してる明るさ の順序㹥變らないが明るさの量は變はつて來る。試料を

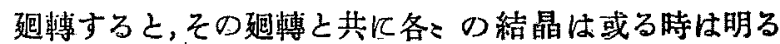
く或る時は暗く交互に明暗を變じ一越轉飞對して 4 回の 變化が起る：郎ち棈圆偏光の明るさは結晶の方向により て定まるてとを示す。プライムローズ(24) (Primrose) は エッチした金風表面を偏光顯微鏡で觀察し，エッチすると 金蠋の表面に多數の微小な凹先が出來るととを明かにし た. 入射した偏光はての凹光で反射して對物レン゙ズに歸 る. この際垂直に反射した光以外の光はての凹坑のため 几位相の差を受ける. ての凹呪の方向が偏光面に平行又 は垂直であれば暗くその他の場合はその方向によりてい

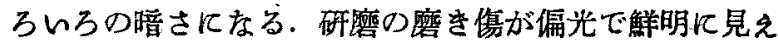
るのはてのためである。

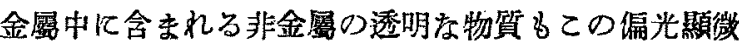
鏡でよく見られる．屡を記载した如く金显の表面からの 反射光收一般棈圆偏光であり，只特别の場合に本而编 光である，棈圆偏光であつても平面偏光に近いから偏光 子之檢光子之を直角に置く之反射光は大體消えて堷く見 える.若し表面に透朋な物體があると，屈折してその中に 入りその物體と金風との境界にて反射して再び表面に出 る. ての光はての物體の形に上りて亂反射をなすから初 めの大射光の如く平面光でなく，その偏光性が失はれる。 從つて檢光子偏光子江直触圈いても明るく見方る。 若し表面加ら直接几反射する光に此して一旦届折した後 几再び表面から出る光が强ければその物體に特有な色が

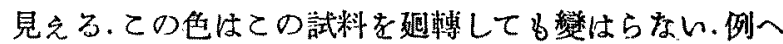
ば錩の中に含まれる亞酸化錩は表面反射の多以普通の光 で見ると青く見えるが偏光子檢光子直角の許では赤く見 える.かやうて物體に特有な色でその物體を識别し得る。

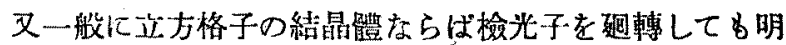
るさは變らないが他の格子型の結昆で检光子の趋轉と 共に交互に明るく喑くなるてとによりてる識別し得る。

(23) R. W. Dayton, Amer. Inst. Min. Metallur. Eng., 116 (1935), 405

(24) Primrose, Metallurgia, 6 (1931), 9. 
シャフマイスター (Schafmeister) 及びモール(25) (Moll) 洁 鐵及び錩中の種々の含有物の識別を試みた。例人泣鍓中 の硫化鐵は秱密格子であるから趣轉之共に明暗を變ずる けれども，硫化アンガンは立方格子であるから暗い，同

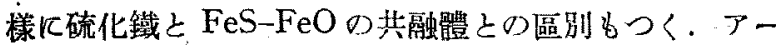
ムコ鐵中の亞酸化鐵もこの方法で見出だされを徭監化錫 のアルコール溶液でェッチして確められたわけである.

鐵釦，以外の金屬合金の場合にも偏光顯微鏡でその含 有物が識別される例は甚だ多い. ダラーザー(26) (Graser) は二つ以上の相上りなる合金の反射光が楕圆偏光である

(25) Schafmeister, Moll Arch. Eisenhüttenwes., (1936 7), 155.
場合には光軸江㨁角行切つた厚さ $3.75 \mathrm{~mm}$ の水晶板を 透すとその相によりて異孝る着色をするてとを見出た゚し 燐青銅之燐之錫之の合金考別してるる.ヌシュワル ッ(27)(Schwarz) 亞酸化銅は透朋で偏光子と檢光子とが 直角め位置では赤く見えるが銅の硫化物，セレンテルル その化合物は不透明であり灰青色涀えるととによりて 雨者を區別し，刃銅，アルミニウム合金中の銅のアルミニ ウム化合物，銅上燐之の合金江於ける銅り燐化合物，青銅 中の酸化錫の檢出を試みてるる。

(26) L. C. Glaser, Z. Tecbn. Phys., 7 (1926), 90

(27) M. Schwarz, Z. Metallk., 7 (1926), 90.

\section{製鋼法の物理化學的研究 (I)}

\section{I. 緒}

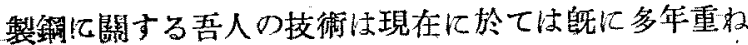
れ種ふ考る觀察と經驗によつて可なりの進步をして居る。 從つて吾人は曥内の作業の條件が變化するとすればてれ，

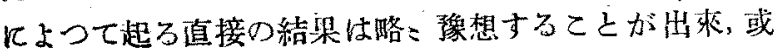
は更汇間接的汇起り得る絈果も亦豫期し得る場合があ る.併してれ等の知識は云はが經驗的技術であつて限ら

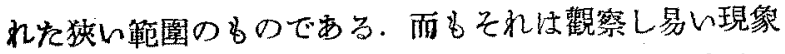
のみを捉人て得たものであるから往々にして原因結果の 關系㜔信してるる場合名少くないであらう，從つてか

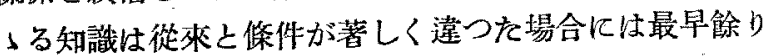
役飞立をなくなつてしまふ。

そてで吾人はての經驗的技䢙の知識を引上げてもつと 廣く且つ深い學術的知識にす多必要があり，てれ机上り

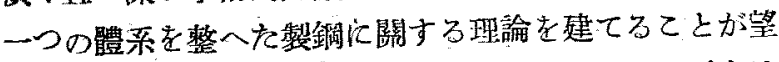
ましい。かくして得を製銅に關する理論によつて吾人は 初めて現行製鈎法を批制しその利點使點を詳かにし更に

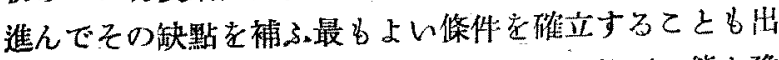
來，又從來之以翼なる新しい製銅作業の可能不可能を稣 知するととも出來るであらう。

かく重要なるへき製鍓化關する理論住現在どらか之

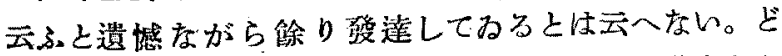
万云ふ譯でての方面の研究が從來崌をとして進京交か つたと云ふとその主なる原因が二つある。その一つは

\footnotetext{
*北海道帝國大學教授
}

\section{柴田善 一*}

從來の銅の製造に對しては上述の經驗的技術で充分間に 合つて居たので殊更その根底的研究を必要としなかつた

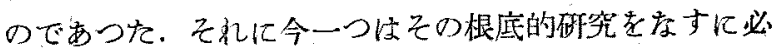

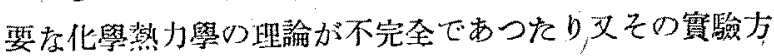
法が極めて困難であつ究がためであつを．然るに近來銅 の物理冶金學的研究の著しい设達に上.り特殊斿成分を有 する種々な銅の製造が要求せられるに至つて最早從來の

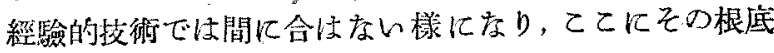

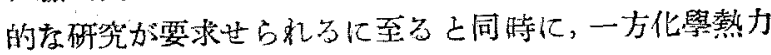
學の理論が進步して來て叉高溫度の賽驗裴置も次第に發 達して來たので最近ての方面の研究は續々發表せられる に至つた。

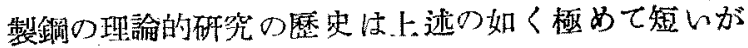
その內ての方面に゙一紀元を畫したのは1925年6月に Faraday Society \& Iron and Steel Instituteの協同開催 による"Physical Chemistry of Steel-making Process”の テーマの下に發表せられた數個の論文である。乙礼は等 ろての方面の誕生口と云つてもよい位で賞時迄の研究は

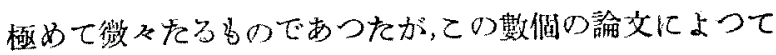
全世界の治金學者は本研垫の必要之興味を感心，皆一齊 にこの研究に着手した㥞である。即台ての方面の硼究諭 文は1929 年頃から著しく㒄加したのでも了解せられる。 その後次第にての方面の研究者は多くなつたがその中最 落名教研究者に米國のC.H. Herty及び J Chipman 獨 逸のF. Körber 及び H.Schenck, 英國のH.Styri 及びMc Cance 等で特に H. Schenck は “Physikalische Chemie 